\title{
Dietary management of inflammatory diseases
}

\author{
Umar Bacha ${ }^{1 *}$, Muhammad A Ali ${ }^{1}$, Abdul Basit $^{2}$, Uzma Litaf $^{3}$ \\ From 7th European Workshop on Immune-Mediated Inflammatory Diseases \\ Noordwijk aan Zee, the Netherlands. 28-30 November 2012
}

Ulcerative colitis and Crohn's disease are inflammatory diseases which are considered to be either associated with the genetic make-up of the individual or due to defective epithelial barrier. In the latter case, environment becomes favorable for proliferation of microorganisms [1] which then causes inflammation. The small intestine expresses gut-associated lymphoid tissue (GALT) to encounter pathogen [2] which (lymph nodes and payer's patches etc.,) changes with changing in colonization of microbes [3]. There are trillion of bacteria on the human gut and this microbiota population depends on nutritional status of the subjects. A healthy nutrition thus promote healthy microflora and vice versa. In some stressful condition (chemotherapy or poor nutrition) the balance in microbiota disturbed. This leads to invasive microbes to invade the gut and intestine. Intestinal cells possess conserve detecting system of bacterial antigens. This leads to progression and regulation of innate and adaptive immune responses. The GALT cells (macrophages, dendritic cells) sense signal from molecules, MHCI, II \& TLRs [4]. It would be imperative to characterize diet that promotes growth of microbes which expresses lipopolysaccharides, peptidoglycan etc., because microbes with the mentioned antigens causes inflammation.
3. Forchielli ML, Walker WA: The role of gut-associated lymphoid tissues and mucosal defence. Br. J. Nutr 2005, 93:S41-S48.

4. Cario E, Brown D, McKee M, Lynch-Devaney K, Gerken G, Podolsk DK: Commensal associated molecular patterns induce selective toll-like receptor-trafficking from apical membrane to cytoplasmic compartments in polarized intestinal epithelium. Am. J. Pathol 2002, 160:165-173.

doi:10.1186/1479-5876-10-S3-P12

Cite this article as: Bacha et al: Dietary management of inflammatory diseases. Journal of Translational Medicine 2012 10(Suppl 3):P12.

\footnotetext{
Author details

${ }^{1}$ Dept. of Food Science \& Human Nutrition, University of Veterinary \& animal Sciences, Lahore, Pakistan. ${ }^{2}$ Kohat Institute of Medical Sciences, Kohat, Pakistan. ${ }^{3}$ Dept. of Food Science \& Technology, Agricultural University Peshawar, Pakistan.

Published: 28 November 2012

\section{References}

1. Paul J, Verma AK, Verma R: Role of gut flora in inflammatory bowel disease- a state of art. Communicating Current Research and Educational Topics and Trends in Applied Microbiology 2007, 705-718.

2. Hakansson A, Molin G: Gut microbiota and inflammation. Nutrients 2011, 3:637-682.

Dept. of Food Science \& Human Nutrition, University of Veterinary \& animal Sciences, Lahore, Pakistan

Full list of author information is available at the end of the article
}

Submit your next manuscript to BioMed Central and take full advantage of:

- Convenient online submission

- Thorough peer review

- No space constraints or color figure charges

- Immediate publication on acceptance

- Inclusion in PubMed, CAS, Scopus and Google Scholar

- Research which is freely available for redistribution 